\title{
Oligocene-Miocene biostratigraphy, magnetostratigraphy, and isotopic stratigraphy of the western North Atlantic
}

\author{
Kenneth G. Miller \\ Lamont-Doherty Geological Observatory of Columbia University, Palisades, New York 10964
}

Marie-Pierre Aubry

Centre de Paléontologie Stratigraphique et Paléoécologie de l'Université Claude Bernard, Villeurbanne, France, and Woods Hole Oceanographic Institution, Woods Hole, Massachusetts 02543

M. J. Khan*

Lamont-Doherty Geological Observatory of Columbia University, Palisades, New York 10964

A. J. Melillo

Department of Geological Sciences, Rutgers University, New Brunswick, New Jersey 08903

D. V. Kent

Lamont-Doherty Geological Observatory of Columbia University, and Department of Geological Sciences, Columbia University, Palisades, New York 10964

\section{W. A. Berggren}

Woods Hole Oceanographic Institution, Woods Hole, Massachusetts 02543 , and Department of Geological Sciences, Brown University, Providence, Rhode Island 02912

\begin{abstract}
Magnetostratigraphic records from western North Atlantic Deep Sea Drilling Project (DSDP) Sites 563 and 558 are correlated with the geomagnetic polarity time scale (GPTS; Berggren et al., 1984a, 1984b) using marine magnetic anomalies and selected biostratigraphic datum levels. The magnetochronology established is used to make direct magnetobiostratigraphic correlations that agree with previous Oligocene-early Miocene studies. However, we show that Zones NN8 partim and NN9 and associated Epoch 11 correlate with Magnetic Anomaly 5 (= Chron C5n). This contrasts with previous indirect correlations of Epoch 11 with Anomaly $5 \mathrm{~A}$ and requires an upward adjustment of 1.5-2.0 m.y. for middle-late Miocene calcareous nannofossil zones. We correlate the middle/late Miocene boundary with Zone NN8 and earliest Chron C5n (10.4 Ma).

\section{INTRODUCTION}

Integrated magnetobiostratigraphic studies of marine sediments (Lowrie et al., 1982; Berggren et al., 1983; Poore et al., 1983; Shackleton et al., 1984a) have allowed the direct correlation of calcareous microfossil first (FO) and last occurrences (LO) with the GPTS. This provides numerical age estimates for biozonal boundaries and chronostratigraphic units by biostratigraphic correlation with the stratotypes. Direct correlations of microfossils with the GPTS have yielded relatively precise numerical age estimates of Oligocene-lower Miocene stage boundaries. However, previous middle-upper Miocene calcareous magnetostratigraphic correlations have been indirect (Ryan et al., 1974; Theyer and Hammond, 1974), resulting in equivocal correlations of the stratotype Langhian, Serravalian, and Tortonian Stages with the GPTS (Berggren et al., 1985a, 1985b). DSDP Sites 563 (lat $33^{\circ} 39^{\prime} \mathrm{N}$, long $43^{\circ} 46^{\prime} \mathrm{W} ; 3796$
\end{abstract}

\footnotetext{
*Present address: Peshawar University, Peshawar, Pakistan.
}

m present water depth) and 558 (lat $37^{\circ} 46^{\prime} \mathrm{N}$, long $37^{\circ} 21^{\prime} \mathrm{W} ; 3754 \mathrm{~m}$ present water depth) provide relatively continuous North Atlantic Oligocene-Miocene records that yield direct correlations of nannofossils, planktonic foraminifera, and isotopes with the GPTS.

\section{METHODS}

Details of magnetostratigraphic techniques and interpretations are given by Khan et al. (1985). Normal and reversed polarity magnetozones are interpreted from remanent inclination directions after selective demagnetization in alternating fields of $10 \mathrm{mT}$ or higher (Figs. 1, 2). Both holes 563 and 558 were rotary cored. Although the effects of drilling disturbance and coring gaps are difficult to avoid completely, we constructed a consistent magnetostratigraphic framework and correlated it with magnetochrons of the GPTS; chron terms and GPTS are derived from Berggren et al. (1985a, 1985b). Planktonic foraminiferal studies (Miller, Melillo, Berggren) and nannofossil studies (Aubry) are based upon qualitative analyses (samples indicated in Figs. 1, 2). Oxygen and carbon isotope analyses were performed upon the benthic foraminifera Cibicidoides (Figs. 1, 2). Procedures and data are given by Miller and Fairbanks (1985). Possible recrystallization of foraminifera was noted in the middle Miocene and lower Oligocene at Site 558 (Fig. 2); therefore, interpretations of Site 558 are tentative. Both sites were located at abyssal depths ( $>2 \mathrm{~km}$ ) during the Oligocene-Miocene.

\section{MAGNETOCHRONOLOGIC FRAMEWORK}

In general, Site 558 contains the better Oligocene magnetostratigraphic record, whereas Site 563 contains the better Miocene record. Apparently, both sites have lower Miocene unconformities.

Site 558 was drilled on crust located between Magnetic Anomalies 13 and 15 (Bougault, Cande, et al., 1985), suggesting that the normal magnetozone found near the base of the hole (Fig. 2) is Chron C13n. With this constraint, the observed polarity sequence can be correlated with the GPTS. Several biostratigraphic datum levels, which have been 


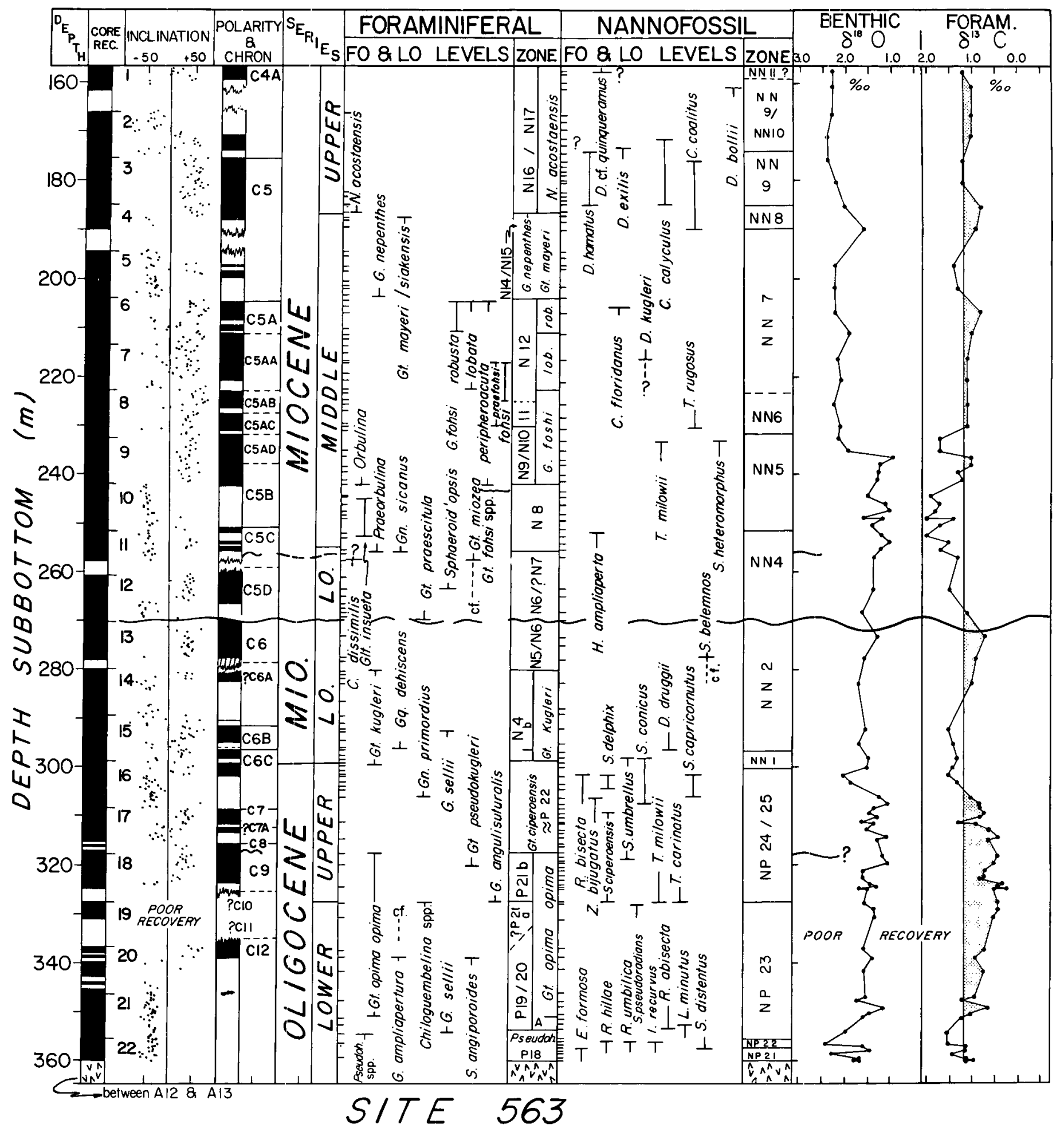

Figure 1. Lower Oligocene-upper Miosene magnetostratigraphy, biostratigraphy, and isotopic stratigraphy of western North Atlantic Site 563. Chron terms after Berggren et al. (1985a, 1985b): e.g., Chron C5 is a time unit corresponding to Anomaly 5 time. Shaded areas in CORE REC. column indicate recovery. Wavy lines at $270 \mathrm{msb}, 255 \mathrm{msb}$, and $317 \mathrm{msb}$ indicate unconformities. Positive or negative inclination values indicate normal (shaded) or reversed (open) magnetic polarity; slashes indicate uncertain polarity. Magnetostratigraphic data after Khan et al. (1985); correlations with Chrons C5AD through C5AA are tentative. Isotopic data relative to PDB standard after Miller and Fairbanks (1985); mean value drawn through carbon isotope data; stipple = values less than mean. Enriched oxygen isotope interval noted near lower/upper Oligocene boundary at Site 558 is missing from this site because of poor recovery (Chrons C10 and C11 are missing). Tick marks indicate levels of samples examined for biostratigraphy. Nannofossil zonation scheme after Martini (1971); planktonic foraminiferal schenne modified after Bolli (1957), Stainforth et al. (1975), Blow (1979), and Kennett and Srinivasan (1983). A = Globigerina ampliapertura Zone. FO = first occurrence of taxa at this location. LO = last occurrence. Series boundaries drawn using magnetobiostratigraphic criteria of Berggren ell al. (1985a, 1985b) and criteria given in text. 
correlated firmly with the GPTS elsewhere, support our correlations. The LO of Chiloguembelina spp. at Sites 558 (Fig. 2), 516 (Pujol, 1983), and 522 (Poore et al., 1983) correlates with Chron C10n. The FO of Globorotalia kugleri was in Chron C6Cn at Sites 558 (Fig. 2), 563 (Fig. 1), and 516 (Berggren et al., 1983). Nannofossils indicate the absence of Zone NN3, suggesting a hiatus for Chron C5E (about 1 m.y.; Figs. 1, 2). The FO of Orbulina spp. was in Chron C5Bn, in agreement with the correlations at Sites 563 (Fig. 1) and 522 (Poore et al., 1983). Poor recovery makes identification of Chrons C5AD-C5A problematic (Fig. 2); a long normal magnetozone occurring in cores 4-6 is correlated with Chron C5n.

Site 563 was drilled between Anomalies 12 and 13 (Bougault, Cande, et al., 1985), suggesting that the long reversed magnetozone noted below $339 \mathrm{~m}$ subbottom (msb) represents Chron $\mathrm{Cl} 2 \mathrm{r}$ (Fig. 1). Poor core recovery precludes identification of Chrons $\mathrm{ClO}$ and $\mathrm{Cl1}$, and
Chrons C9 and C8 are apparently concatenated (Fig. 1). Correlations near the lower/upper Oligocene boundary are therefore uncertain. The FO of Globorotalia kugleri is associated with the lower of two normal magnetozones correlated with Chron $\mathrm{C} 6 \mathrm{C}$, agreeing with correlations noted above. As at Site 558, a missing section or sections is recognized in the lower Miocene (between cores 12 and 13 and/or near the base of core 11). The absence of nannofossil Zone NN3 suggests that the unconformity occurs at the base of core 12 with Chron CSE (about 1 m.y.) missing (Fig. 1). The first occurrence of Orbulina spp. occurs at the base of a normal magnetozone correlated with Chron C5Bn, as noted at Sites 521 and 558 . The predominantly normal interval punctuated by short reversed magnetozones in cores 6 through 9 is tentatively correlated with Chrons C5AD through C5A. Therefore, the long normal magnetozone encountered in cores 3 and 4 (Fig. 1) is correlated with Chron C5n (= Anomaly 5).

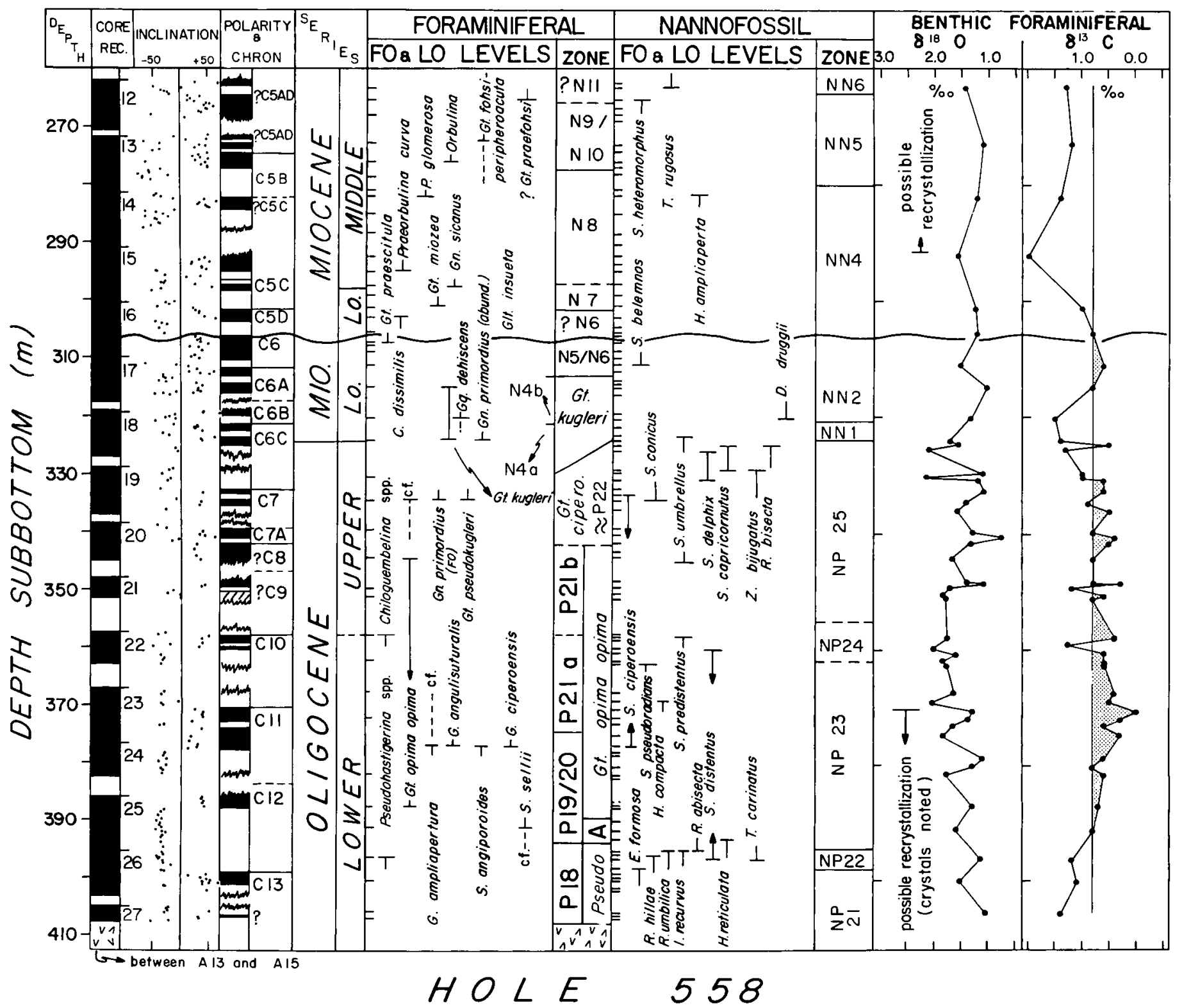

Figure 2. Lower Oligocene-middle Miocene stratigraphy of western North Atlantic Site 558. Description as in Figure 1. Wavy line at 307 msb indicates unconformity. Recovery of cores 7-11 was poor; therefore, data for cores 1-11 are not shown but are available on request from Miller. 


\section{PLANKTONIC FORAMINIFERAL, BIOSTRATIGRAPHY}

The classic tropical zonations of Bolli (1957) and Blow (1979) are only partially applicable at these mid-latitude, subtropical gyre locations. Globorotalia opima opima (>390 $\mu \mathrm{m})$ first occurred in Chron $\mathrm{C1} 2 \mathrm{n}$ at Site 558 (Fig. 2). At Site 563 (Fig. 1) it apparently occurred even earlier (Chron C12r) immediately after the LO of Pseudohastigerina spp. (effectively eliminating $G$. ampliapertura Zone). Globigerinoides primordius first occurred in late Oligocene Chron $\mathrm{C6Cr}$ at both sites (Figs. 1, 2), in agreement with Berggren et al. (1985a, 1.985b and references therein), but in contrast to Blow (1979). The FO of Gt fohsi peripheroacuta and the FO Orbulina spp. are closely associated at both sites, suggesting the elimination of Zone N9. The FO of Globigerina nepenthes immediately after both Chron C5An and the LO of Globorotalia fohsi ssp. (Fig. 1) suggest the elimination of Zone N13 (sensu Kennett and Srinivasan, 1983). Similarly, Zone N15 (sensu Blow, 1979) is eliminated by the virtual overlap of Gt mayeri/siakensis and Neogloboquadrina acostaensis (Fig. 1). As the magnetostratigraphic reciord is fairly complete, we believe that the elimination of these zones at these locations is due not to hiatuses but to latitudinal diachrony. Further documentation of these apparently diachronous ranges is needed.

At Site 563, Catapsydrax dissimilis disappears just below the FO of Praeorbulina spp. This indicates that Zone N7 is missing; it is apparently present at Site 558. This suggests a hiatus (Chron C5C partim) at Site 563.

Controversy surrounds the placement of the Oligocene/Miocene boundary. Berggren et al. (1985a, 1985b) recognized the boundary using the FO of Globorotalia kugleri, whereas Kennett and Srinivasan (1983) used the FO of Globoquadrina dehiscens. We note that at Sites 563 and 558 (Figs. 1, 2) these events were linked with Chrons C6Cn (at 23.7 Ma) and $\mathrm{C} 6 \mathrm{Br}$ (at $23.2 \mathrm{Ma}$ ), respectively, and that both events postdated a sharp oxygen iostope enrichment that occurred in $\mathrm{Chron} \mathrm{C6Cr}$ (at 24-25 Ma; Figs. 1, 2). These stratigraphic relationships show a remarkable consistency between sites. We arbitrarily place the boundary in Chron $\mathrm{C} 6 \mathrm{Cn}$ in association with the FO of G. kugleri

\section{NANNOFOSSIL BIOSTRATIGRAPHY}

We were able to apply Martini's (1971) standard zonation at Sites 558 and 563 except that (1) in the lower-middle Miocene poor preservation precluded accurate recognition of the FO and LO of some stratigraphically useful discoasters (i.e., $D$. formosus, $D$. exilis, $D$. variabilis, D. challengeri); (2) in the upper Miocene preservation is poor; (3) some local early FO were observed (e.g., Sphenolithus ciperoensis, Site 558; Fig. 2); and (4) some index species were rare (S. distentus, Helicosphaera ampliaperta, D. kugleri). On the basis of nannofossil evidence, a lower Miocene unconformity is postulated for both sites (Zone NN3 is missing). At Site 558 (Fig. 2), reworking is suggested above the unconformity (core 16-4) by the anomalous co-occurrence of Triquetrorhabdulus carinatus, $S$. belemnos, and $S$. heteromorphus. At Site 563, Zone NN2 (with $T$. carinatus and $S$. belemnos) is overlain by Zone NN4 (with $S$. heteromorphus and $H$. ampliaperta).

Diverse, well-preserved Oligocene and lower-upper Miocene nannofossils allow firm correlations. The LO of Reticulofenestra bisecta is closely associated with the FO of Globorotalia kugleri and Chron $\mathrm{C} 6 \mathrm{Cn}$ as noted at Sites 516 and 522 (Berggren et al., 1983; Poore et al., 1983; see above). At Site 563, Zones NN8 partim and NN9 are associated with Chron C5n (Fig. 1); this is supported by correlations at Sites 521 A, 519 (Hsü, La Brecque, et al., 1984), and 558. Clur correlations suggest the following revised magnetochronologic boundary ages: (1) NN7/NN8 = $10.8 \mathrm{Ma}$, and (2) NN8/NN9 $=10.0 \mathrm{Ma}$.

\section{ISOTOPIC STRATIGRAPHY}

At site 563 , high $\delta^{18} \mathrm{O}$ values $(>2.0 \%$ ) in benthic foraminifera occur in the lower Oligocene (within Chron C12r), upper Oligocene
(Chron $\mathrm{C6Cr}$; magnetochronologic age estimate 25-24 Ma), and middle Miocene (Chron C5Bn; age estimate $14.7 \mathrm{Ma}$ ) to the top of the hole (Fig. 1). At Site 558, the upper Oligocene (25-24 Ma) enriched interval also is present; in addition, an enriched interval occurs across the lower /upper Oligocene boundary (Chrons C11n-C9n; 31-28 Ma; Fig. 2). This latter interval correlates with an enriched interval noted at equatorial Pacific sites (Keigwin and Keller, 1985; Miller and Thomas, 1985). The earliest Oligocene enriched interval may correlate with high $\delta^{18} \mathrm{O}$ values noted elsewhere following the Eocene/Oligocene boundary increase (Keigwin, 1980; Poore and Matthews, 1984; Snyder et al., 1984, among others), although the highest values elsewhere occurred at ca. 36-35 Ma, and a precise correlation is not possible. The 14.7 Ma enrichment correlates precisely with the well-established middle Miocene ${ }^{18} \mathrm{O}$ enrichment (Savin et al., 1975, 1981; Shackleton and Kennett, 1975, among others). The 25-24 Ma enriched interval has not been noted elsewhere, presumably owing to lack of study of upper Oligocene sediments. The intervals of enriched ${ }^{18} \mathrm{O}$ are interpreted as periods of continental glaciation and lowered sea level at ca. 36-35, 31-28, 25-24, and younger than 14.7 Ma (Miller and Fairbanks, 1983, 1985; Keigwin and Keller, 1984; Miller and Thomas, 198.5; Poore and Matthews, 1984; Shackleton et al., 1984b).

The benthic foraminiferal $\delta^{13} \mathrm{C}$ record documents three cycles of enrichments and depletions, with enriched intervals in Chron $\mathrm{C} 12 \mathrm{n}$ (34.5-33 Ma), C6An-C6Cr (25.5-22 Ma), and C5D-C5AD (18-14 Ma) (Figs. 1, 2). Similar $\delta^{13} \mathrm{C}$ fluctuations occurred in benthic and planktonic foraminifera from the Atlantic, Pacific, and Indian oceans, indicating that these cycles represent global changes in the mean ${ }^{13} \mathrm{C}$ of seawater (Miller and Fairbanks, 1985).

\section{DISCUSSION: IMPLICATIONS FOR THE AGE OF THE MIDDLE/LATE MIOCENE BOUNDARY}

Our Oligocene-lower Miocene magnetobiostratigraphic correlations agree with previous studies (Lowrie et al., 1982; Berggren et al., 1983; Poore et al., 1983; Pujol, 1983). However, our middle-upper Miocene correlations conflict with those of previous workers. In particular, Ryan et al. (1974) suggested that Epoch 9 was correlated with Anomaly 5 and Epoch 11 with Anomaly 5A. We reevaluate this interpretation based on the following: (1) Zone NN9 is associated with Epoch 11 at piston core RC12-65 (Ryan et al., 1974), and (2) at Sites 563 (Fig. 1) and 558, Zones NN8 (partim) and NN9 are associated with a long normal magnetozone that we correlate with Chron $\mathrm{C} 5 \mathrm{n}$ (Anomaly 5). We suggest that Epoch 11 correlates with Anomaly 5 as suggested by Foster and Opdyke (1970). The upward shift of Zone NN9 relative to the GPTS requires an adjustment of 1.5-2.0 m.y. for Zones NN8-NN11.

These magnetobiostratigraphic re-correlations require chronostratigraphic changes. The stratotype Tortonian (lower-upper Miocene) contains Zones NN8 (partim) to NN1 1 (partim); the base of the stratotype is associated with Zone NN8 and the FO of $N$. acostaensis (references in Berggren et al., 1985a). At Sites 563 and 558, the FO of $N$. acostaensis and Zone NN8 occurred in earliest Chron C5n (Fig. 1). The middle/late Miocene boundary (= basal Tortonian) can be approximated as the earliest Chron C5n; it therefore has a magnetochronologic age of $10.4 \mathrm{Ma}$ (GPTS of Berggren et al., 1985a). This contrasts with previous biochronologic age estimates of 11.2 Ma (Berggren and Van Couvering, 1974). Considering the importance of these proposed changes to middle-late Miocene stratigraphy (Berggren et al., 1985a), further studies confirming these magnetostratigraphic relationships are desirable. 


\section{REFERENCES CITED}

Berggren, W.A., and Van Couvering, J.A., 1974, The Late Neogene: Biostratigraphy, geochronology, and paleoclimatology of the last 15 million years in marine and continental sequences: Palaeogeography, Palaeoclimatology, Palaeoecology, v. 16, p. 1-216.

Berggren, W.A., Aubry, M.-P., and Hamilton, N., 1983, Neogene magnetobiostratigraphy of Deep Sea Drilling Project Site 516 (Rio Grande Rise, South Atlantic), in Barker, P.F., Carlson, R.L., Johnson, D.A., et al., Initial reports of the Deep Sea Drilling Project, Volume 73: Washington, D.C., U.S. Government Printing Office, p. 675-713.

Berggren, W.A., Kent, D.V., and Van Couvering, J.A., 1985a, Neogene geochronology and chronostratigraphy, in Snelling, N.J., ed., Geochronology and the geologic time scale: Geological Society of London Special Publication.

Berggren, W.A., Kent, D.V., and Flynn, J., 1985b, Paleogene geochronology and chronostratigraphy, in Snelling, N.J., ed., Geochronology and the geologic time scale: Geological Society of London Special Publication.

Blow, W.H., 1979, The Cainozoic Globigerinida: Leiden, E.J. Brill, 1413 p.

Bolli, H.M., 1957, Planktonic foraminifera from the Oligocene-Miocene Cipero and Lengua Formations of Trinidad, B.W.I.: U.S. National Museum Bulletin 215, p. 97-123.

Bougault, H., Cande, S.C., et al., 1985, Initial reports of the Deep Sea Drilling Project, Volume 82: Washington, D.C., U.S. Government Printing Office.

Foster, J.H., and Opdyke, N.D., 1970, Upper Miocene to Recent magnetic stratigraphy in deep-sea sediments: Journal of Geophysical Research, v. 75, p. 4465-4473.

Hsü, K.J., LaBrecque, J.L., et al., 1984, Numerical ages of Cenozoic biostratigraphic datum levels: Results of Leg 73 drilling: Geological Society of America Bulletin, v. 95, p. 863-876.

Keigwin, L.D., 1980, Palaeoceanographic change in the Pacific at the EoceneOligocene boundary: Nature, v. 287, p. 722-725.

Keigwin, L.D., and Keller, G., 1984, Middle Oligocene climatic change from equatorial Pacific DSDP Site 77: Geology, v. 12, p. 16-19.

Kennett, J.P., and Srinivasan, M.S., 1983, Neogene planktonic foraminifera: A phylogenetic atlas: Stroudsburg, Pennsylvania, Hutchinson and Ross, 265 p.

Khan, M.J., Kent, D.V., and Miller, K.G., 1985, Magnetostratigraphy of Oligocene to Pleistocene sediments of DSDP Leg 82, in Bougault, H., Cande, S.C. et al., Initial reports of the Deep Sea Drilling Project, Volume 82: Washington, D.C., U.S. Government Printing Office.

Lowrie, W., Alvarez, W., Napoleone, G., Perch-Nielson, K., Premoli-Silva, I., and Toumarkine, M., 1982, Paleogene magnetic stratigraphy in Umbrian pelagic carbonate rocks: The Contessa sections, Gubbio: Geological Society of America Bulletin, v. 93, p. 414-432.

Martini, E., 1971, Standard Tertiary and Quaternary calcareous nannoplankton zonation, in Fainacci, A., ed., Proceedings of the Second Planktonic Conference, Roma, 1971: Rome, Edizioni Tecnoscienza, p. 739-785.

Miller, K.G., and Fairbanks, R.G., 1983, Evidence for Oligocene-middle Miocene abyssal circulation changes in the western North Atlantic: Nature, v. 306, p. 250-252.

- 1985, Oligocene-Miocene global carbon and abyssal circulation changes, in Sundquist, E., and Broecker, W., eds., Chapman Conference on Natural Variations in Carbon Dioxide and the Carbon Cycle: American Geophysical Union Monograph.

Miller, K.G., and Thomas, E., 1985, Late Eocene to Oligocene benthic foraminiferal isotopic record, Site 574 equatorial Pacific, in Mayer, L., Theyer, F., et al., Initial reports of the Deep Sea Drilling Project, Volume 85: Washington, D.C., U.S. Government Printing Office.

Poore, R.Z., and Matthews, R.K., 1984, Late Eocene-Oligocene oxygen and carbon isotope record from South Atlantic Ocean DSDP Site 522, in Hsü, K.J. La Brecque, J.L., et al., Initial reports of the Deep Sea Drilling Project, Volume 73: Washington, D.C., U.S. Government Printing Office, p. 725-736.

Poore, R.Z., Tauxe, L., Percival, S.F., LaBrecque, J.L., Wright, R, Petersen, N.P., Smith, C.C., Tucker, P., and Hsü, K.J., 1983, Late Cretaceous-Cenozoic magnetostratigraphic and biostratigraphic correlations of the South Atlantic Ocean: DSDP Leg 73: Palaeogeography, Palaeoclimatology, Palaeocology, v. 42 , p. $127-149$.
Pujol, C., 1983, Cenozoic planktonic foraminiferal biostratigraphy of the southwest Atlantic (Rio Grande Rise), in Barker, P.F., Carlson, R.L., Johnson, D.A., et al., Initial reports of the Deep Sea Drilling Project, Volume 72: Washington, D.C., U.S. Government Printing Office, p. 623-673.

Ryan, W.B.F., Cita, M.B., Dreyfus Rawson, M., Burkle, L.H., and Saito, T., 1974, A paleomagnetic assignment of Neogene stage boundaries and the development of isochronous datum planes between the Mediterranean, the Pacific, and Indian Oceans in order to investigate the response of the world ocean to the Mediterranean "salinity crisis": Rivista Italiana Paleontologia e Stratigrafia, v. 80, p. 631-688.

Savin, S.M., Douglas, R.G., and Stehli, F.G., 1975, Tertiary marine paleotemperatures: Geological Society of America Bulletin, v. 86, p. 1499-1510.

Savin, S.M., Douglas, R.G., Keller, G., Killingley, J.S., Shaughnessy, L., Sommer, M.A., Vincent, E., and Woodruff, F., 1981, Miocene benthic foraminiferal isotope records: A synthesis: Marine Micropaleontology, v. 6, p. 423-450.

Shackleton, N.J., and Kennett, J.P., 1975, Paleotemperature history of the Cenozoic and the initiation of Antarctic glaciation: Oxygen and carbon isotopic analyses in DSDP Sites 277,279 , and 281 , in Kennett, J.P., and Houtz, R.E., et al., Initial reports of the Deep Sea Drilling Project, Volume 29: Washington, D.C., U.S. Government Printing Office, p.743-755.

Shackleton, N.J., et al., 1984a, Accumulation rates in Leg 74 sediments, in Moore, T.C., and Rabinowitz, P.D., et al., Initial reports of the Deep Sea Drilling Project, Volume 74: Washington, D.C., U.S. Government Printing Office, p. 621-637.

Shackleton, N.J., Hall, M.A., and Boersma, A., 1984b, Oxygen and carbon isotope data from Leg 74 foraminifers, in Moore, T.C., and Rabinowitz, P.D., et al., Initial reports of the Deep Sea Drilling Project, Volume 74: Washington, D.C., U.S. Government Printing Office, p. 599-612.

Snyder, S.W., Muller, C., and Miller, K.G., 1984, Biostratigraphy and paleoceanography across the Eocene/Oligocene boundary at Deep Sea Drilling Project Site 549: Geology, v. 12, p. 112-115.

Stainforth, R.M., Lamb, J.L., Luterbacher, H., Beard, J.H., and Jeffords, R.M., 1975, Cenozoic planktonic foraminiferal zonation and characteristic index forms: University of Kansas Paleontological Contributions Article 62, 162 p.

Theyer, F., and Hammond, S.R., 1974, Paleomagnetic polarity sequence and radiolarian zones, Brunhes to polarity epoch 20: Earth and Planetary Science Letters, v. 22, p. 307-319.

\section{ACKNOWLEDGMENTS}

Reviewed by L. D. Burckle, B. M. Clement, N. D. Opdyke, and R. Z. Poore Supported by National Science Foundation Grants OCE83-10086 (Miller) and OCE83-00356 (Kent). We thank H. M. Bolli, S. C. Cande, B. M. Clement, R. G. Fairbanks, R. K. Olsson, M. E. Parker, R. Z. Poore, L. Tauxe, and S. W. Wise for discussions of the problem and A. Dragonovich for drafting the figures. Samples provided by the DSDP. Lamont-Doherty Geological Observatory Contribution No. 3735 and Woods Hole Oceanographic Institution Contribution No. 5850.

Manuscript received August 13, 1984

Revised manuscript received December 3, 1984

Manuscript accepted December 21, 1984

\section{Reviewer's comment}

Provides important new data bearing on establishing calibrations between the polarity time scale-biostratigraphic zonations and European stratotypes.

Richard Poore 